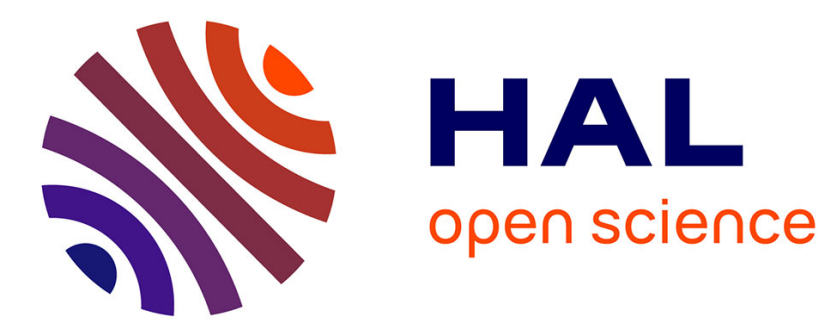

\title{
Phytoliths as a seasonality indicator? The example of the Neolithic site of Pendimoun, south-eastern France
}

Claire Delhon, Didier Binder, Pascal Verdin, Arnaud Mazuy

\section{To cite this version:}

Claire Delhon, Didier Binder, Pascal Verdin, Arnaud Mazuy. Phytoliths as a seasonality indicator? The example of the Neolithic site of Pendimoun, south-eastern France. Vegetation History and Archaeobotany, 2020, 29, pp.229-240. 10.1007/s00334-019-00739-0 . hal-02391424

\section{HAL Id: hal-02391424 \\ https://hal.science/hal-02391424}

Submitted on 16 Nov 2021

HAL is a multi-disciplinary open access archive for the deposit and dissemination of scientific research documents, whether they are published or not. The documents may come from teaching and research institutions in France or abroad, or from public or private research centers.
L'archive ouverte pluridisciplinaire $\mathbf{H A L}$, est destinée au dépôt et à la diffusion de documents scientifiques de niveau recherche, publiés ou non, émanant des établissements d'enseignement et de recherche français ou étrangers, des laboratoires publics ou privés. 
Dear Author,

Here are the proofs of your article.

- You can submit your corrections online, via e-mail or by fax.

- For online submission please insert your corrections in the online correction form. Always indicate the line number to which the correction refers.

- You can also insert your corrections in the proof PDF and email the annotated PDF.

- For fax submission, please ensure that your corrections are clearly legible. Use a fine black pen and write the correction in the margin, not too close to the edge of the page.

- Remember to note the journal title, article number, and your name when sending your response via e-mail or fax.

- Check the metadata sheet to make sure that the header information, especially author names and the corresponding affiliations are correctly shown.

- Check the questions that may have arisen during copy editing and insert your answers/ corrections.

- Check that the text is complete and that all figures, tables and their legends are included. Also check the accuracy of special characters, equations, and electronic supplementary material if applicable. If necessary refer to the Edited manuscript.

- The publication of inaccurate data such as dosages and units can have serious consequences. Please take particular care that all such details are correct.

- Please do not make changes that involve only matters of style. We have generally introduced forms that follow the journal's style.

Substantial changes in content, e.g., new results, corrected values, title and authorship are not allowed without the approval of the responsible editor. In such a case, please contact the Editorial Office and return his/her consent together with the proof.

- If we do not receive your corrections within $\mathbf{4 8}$ hours, we will send you a reminder.

- Your article will be published Online First approximately one week after receipt of your corrected proofs. This is the official first publication citable with the DOI. Further changes are, therefore, not possible.

- The printed version will follow in a forthcoming issue.

\section{Please note}

After online publication, subscribers (personal/institutional) to this journal will have access to the complete article via the DOI using the URL: http://dx.doi.org/[DOI].

If you would like to know when your article has been published online, take advantage of our free alert service. For registration and further information go to: http://www.link.springer.com.

Due to the electronic nature of the procedure, the manuscript and the original figures will only be returned to you on special request. When you return your corrections, please inform us if you would like to have these documents returned. 


\section{Metadata of the article that will be visualized in OnlineFirst}

\begin{tabular}{|c|c|c|}
\hline ArticleTitle & \multicolumn{2}{|c|}{$\begin{array}{l}\text { Phytoliths as a seasonality indicator? The example of the Neolithic site of Pendimoun, south-eastern } \\
\text { France }\end{array}$} \\
\hline \multicolumn{3}{|l|}{ Article Sub-Title } \\
\hline Article CopyRight & \multicolumn{2}{|c|}{$\begin{array}{l}\text { Springer-Verlag GmbH Germany, part of Springer Nature } \\
\text { (This will be the copyright line in the final PDF) }\end{array}$} \\
\hline Journal Name & \multicolumn{2}{|c|}{ Vegetation History and Archaeobotany } \\
\hline \multirow[t]{12}{*}{ Corresponding Author } & Family Name & Delhon \\
\hline & Particle & \\
\hline & Given Name & Claire \\
\hline & Suffix & \\
\hline & Division & \\
\hline & Organization & Université Côte d'Azur, CNRS, CEPAM (UMR 7264) \\
\hline & Address & $\begin{array}{l}\text { Campus Saint-Jean d'Angély 3, } 24 \text { avenue des Diables Bleus, 06357, Nice } \\
\text { cedex 4, France }\end{array}$ \\
\hline & Phone & \\
\hline & Fax & \\
\hline & Email & claire.delhon@cepam.cnrs.fr \\
\hline & URL & \\
\hline & ORCID & http://orcid.org/0000-0002-7216-0148 \\
\hline \multirow[t]{12}{*}{ Author } & Family Name & Binder \\
\hline & Particle & \\
\hline & Given Name & Didier \\
\hline & Suffix & \\
\hline & Division & \\
\hline & Organization & Université Côte d'Azur, CNRS, CEPAM (UMR 7264) \\
\hline & Address & $\begin{array}{l}\text { Campus Saint-Jean d'Angély 3, } 24 \text { avenue des Diables Bleus, 06357, Nice } \\
\text { cedex 4, France }\end{array}$ \\
\hline & Phone & \\
\hline & Fax & \\
\hline & Email & \\
\hline & URL & \\
\hline & ORCID & \\
\hline \multirow[t]{8}{*}{ Author } & Family Name & Verdin \\
\hline & Particle & \\
\hline & Given Name & Pascal \\
\hline & Suffix & \\
\hline & Division & \\
\hline & Organization & Université Côte d'Azur, CNRS, CEPAM (UMR 7264) \\
\hline & Address & $\begin{array}{l}\text { Campus Saint-Jean d'Angély 3, } 24 \text { avenue des Diables Bleus, 06357, Nice } \\
\text { cedex 4, France }\end{array}$ \\
\hline & Phone & \\
\hline
\end{tabular}


Fax

Email

URL

ORCID

\begin{tabular}{|c|c|c|}
\hline \multirow[t]{13}{*}{ Author } & Family Name & Mazuy \\
\hline & Particle & \\
\hline & Given Name & Arnaud \\
\hline & Suffix & \\
\hline & Division & \\
\hline & Organization & Université Côte d'Azur, CNRS, CEPAM (UMR 7264) \\
\hline & Address & $\begin{array}{l}\text { Campus Saint-Jean d'Angély 3, } 24 \text { avenue des Diables Bleus, 06357, Nice } \\
\text { cedex 4, France }\end{array}$ \\
\hline & Phone & \\
\hline & Fax & \\
\hline & Email & \\
\hline & URL & \\
\hline & ORCID & \\
\hline & Received & 26 October 2017 \\
\hline \multirow[t]{2}{*}{ Schedule } & Revised & \\
\hline & Accepted & 11 July 2019 \\
\hline Abstract & \multicolumn{2}{|c|}{$\begin{array}{l}\text { Pendimoun rock-shelter is among the oldest Neolithic sites known on the French littoral (Impressa culture, } \\
\text { since ca. } 5700 \text { BCE). It was discontinuously occupied from the Mesolithic to the end of the Neolithic. } \\
\text { During the Neolithic, it was used for pastoral purposes and domestic activities as well as for pottery } \\
\text { production. Agriculture and cereal processing are clearly attested during the Impressa occupation (grains, } \\
\text { husk and straw macroremains, grindstones) and become more less obvious in the overlying layers. } \\
\text { Phytolith analysis concerned } 1 \text { Mesolithic sample (Sauveterrian culture) and } 16 \text { samples covering most of } \\
\text { the 6th millennium BCE (Impressa, Cardial, and transition to Early Square Mouthed Pottery-SMP } \\
\text { cultures). Significant amounts of grass phytoliths and the scarcity of dicot phytoliths suggest that the } \\
\text { livestock, whose dung constitutes an important part of the sediment, mainly fed on wild grasses. } \\
\text { Inflorescence bract phytoliths are well represented only in the Impressa levels, confirming that cereals } \\
\text { were partly processed in situ only during the earliest stages of the Neolithic. Amounts of BILOBATE short } \\
\text { cells proved to be higher than expected in an area where only a few panicoid species can grow. The three } \\
\text { candidates for BILOBATE phytolith producers (Setaria spp., Digitaria sanguinalis, Echinochloa crus-galli) } \\
\text { all have a short vegetation cycle that lies entirely between the end of spring and the beginning of autumn, } \\
\text { suggesting that the shelter was mainly used during that period. The low amount of inflorescence bract } \\
\text { phytoliths (except during the Impressa) seems to restrict that range to the period before the ears become } \\
\text { mature, namely the end of spring or early summer. }\end{array}$} \\
\hline Keywords (separated by '-') & \multicolumn{2}{|c|}{ Phytolith - Neolithic - South-eastern France - Seasonality - Panicoideae - Pastoralism } \\
\hline Footnote Information & \multicolumn{2}{|c|}{ Communicated by K. Neumann. } \\
\hline
\end{tabular}




\title{
2 Phytoliths as a seasonality indicator? The example of the Neolithic site of Pendimoun, south-eastern France
}

\author{
4 Claire Delhon $^{1}{ }^{1} \cdot$ Didier Binder $^{1} \cdot$ Pascal Verdin $^{1} \cdot$ Arnaud Mazuy $^{1}$
}

\section{Abstract}

Received: 26 October 2017 / Accepted: 11 July 2019

(c) Springer-Verlag GmbH Germany, part of Springer Nature 2019

\begin{abstract}
Pendimoun rock-shelter is among the oldest Neolithic sites known on the French littoral (Impressa culture, since ca. 5700 BCE). It was discontinuously occupied from the Mesolithic to the end of the Neolithic. During the Neolithic, it was used for pastoral purposes and domestic activities as well as for pottery production. Agriculture and cereal processing are clearly attested during the Impressa occupation (grains, husk and straw macroremains, grindstones) and become more less obvious in the overlying layers. Phytolith analysis concerned 1 Mesolithic sample (Sauveterrian culture) and 16 samples covering most of the 6th millennium BCE (Impressa, Cardial, and transition to Early Square Mouthed Pottery-SMP cultures). Significant amounts of grass phytoliths and the scarcity of dicot phytoliths suggest that the livestock, whose dung constitutes an important part of the sediment, mainly fed on wild grasses. Inflorescence bract phytoliths are well represented only in the Impressa levels, confirming that cereals were partly processed in situ only during the earliest stages of the Neolithic. Amounts of BILOBATE short cells proved to be higher than expected in an area where only a few panicoid species can grow. The three candidates for BiLoвate phytolith producers (Setaria spp., Digitaria sanguinalis, Echinochloa crus-galli) all have a short vegetation cycle that lies entirely between the end of spring and the beginning of autumn, suggesting that the shelter was mainly used during that period. The low amount of inflorescence bract phytoliths (except during the Impressa) seems to restrict that range to the period before the ears become mature, namely the end of spring or early summer.
\end{abstract}

\section{Keywords Phytolith $\cdot$ Neolithic $\cdot$ South-eastern France $\cdot$ Seasonality $\cdot$ Panicoideae $\cdot$ Pastoralism}

\section{Introduction}

Pendimoun is a very important site for understanding of the Neolithic transition in the northwestern Mediterranean. Farming economies, which spread throughout the NearEast and the Aegean, reached southern Italy shortly after 6000 BCE (Binder et al. 2017). The Neolithic innovations were brought to the Western Mediterranean by groups of pioneers belonging to the Impresso-cardial cultural complex who arrived by sea from Italy. These groups settled close to the littoral, while parts of the hinterlands were still occupied by Late Mesolithic groups. These pioneer populations are

Communicated by K. Neumann.

Claire Delhon

claire.delhon@cepam.cnrs.fr

1 Université Côte d'Azur, CNRS, CEPAM (UMR 7264), Campus Saint-Jean d'Angély 3, 24 avenue des Diables Bleus, 06357 Nice cedex 4, France known thanks to a very small number of sites, scattered from Liguria in Italy to the south-eastern Languedoc in France. Pendimoun is one of these few key-sites documenting the very beginning of agro-pastoral economies in south-western Europe. With the spread of agriculture, questions arise concerning the ways prehistoric farmers exploited the territory and managed their resources. In particular, the mobility of the groups and the duration of the occupations, which seem to be linked to the kinds of activities carried out at the sites, remain difficult to assess accurately. Due to the scarcity of archaeological sites and to preservation hazards, plant and animal remains linked to human activities are rare. Therefore, as many as possible of the recovered remains need to be fully exploited and studies must extend beyond the most obvious macroremains. Phytolith analysis has proved to be an effective tool for obtaining reliable quantitative information concerning plant-related activities (and more specifically agriculture and farming), particularly in contexts where organic remains are poorly preserved or scarce (Harvey and Fuller 2005; Delhon et al. 2008; Cabanes et al. 2009;

\begin{tabular}{|l|l|l|l|l|}
\hline Journal : Large 334 & Article No : 739 & Pages : 12 & MS Code : 739 & Dispatch : 13-7-2019 \\
\hline
\end{tabular}


Lancelotti et al. 2014). In our study, phytolith analysis of Early Neolithic levels at Pendimoun shelter has been used as a means, among others (there are several ongoing studies concerning the same site which rely on a wide range of analytic approaches: see Binder et al. in press), of documenting agro-pastoral activities.

\section{Archaeological background}

Pendimoun is a rock-shelter located in south-eastern France, near the Italian border, just above the City of Menton (Fig. 1). Due to the steep topography, this can be considered to be both a coastal site (at less than $4 \mathrm{~km}$ from the sea as the crow flies) as well as a low mountain site (at an elevation of nearly $700 \mathrm{~m}$ ). The site is currently on the ecotone between Meso- and Supramediterranean Vegetation Belts and the surrounding landscape is strongly characterized by pastoral exploitation. The site was first explored in the 1950s, and more recent excavations carried out by Didier Binder between 1985 and 2006 have revealed a discontinuous occupation from the Mesolithic to the end of the Neolithic. The southern and northern sectors of the site are separated by a trench inherited from the old excavation, which unfortunately hinders any strict correlation between the two stratigraphies (Binder et al. 1993).

The oldest archaeological level is attributed to the Sauveterrian Mesolithic culture of the 9th millennium BCE and it is notably represented by an infant burial. Around $80 \mathrm{~cm}$ above this level, the Neolithic sequence stretches over a thickness of ca. $200 \mathrm{~cm}$ and records occupations from the Impressa Neolithic (Early 6th millennium BCE) to the Bell Beaker cultural complex (Late 3rd millennium BCE). Despite the fact that the two sectors of the site are now disconnected, it appears that the Impressa deposits from the southern sector predate those from the northern sector. The sequence also includes several archaeological discontinuities due to periods of abandonment of the site and/or to erosion. The
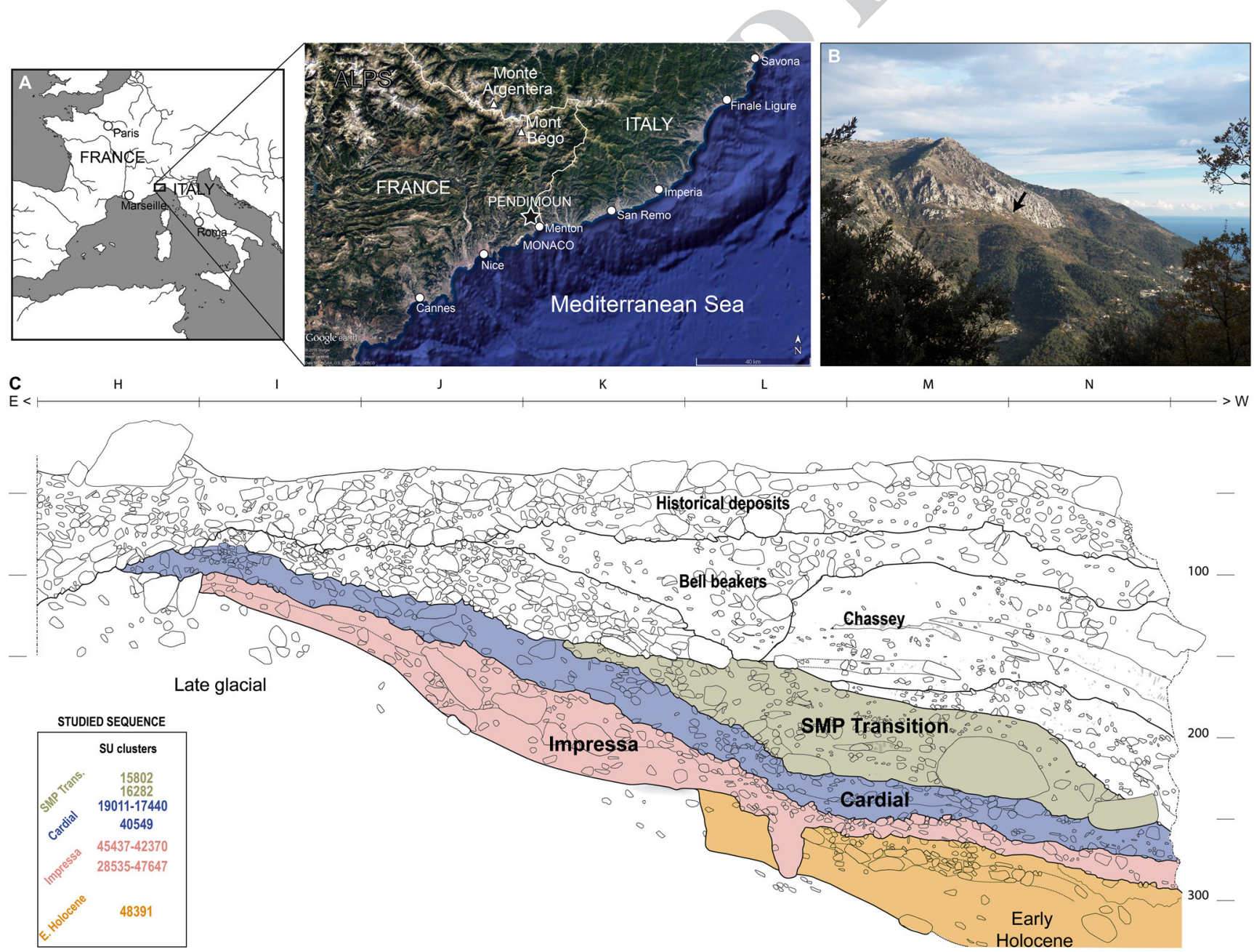

Fig. 1 Site location in south-eastern France (a), general overview of the shelter (b photograph JV Pradeau) and stratigraphic sequence of the northern sector (c east/west section)

\begin{tabular}{|l|l|l|l|l|}
\hline Journal : Large 334 & Article No : 739 & Pages : 12 & MS Code : 739 & Dispatch : 13-7-2019 \\
\hline
\end{tabular}


identification of sheep bones and the composition of the sediment, partly made up of mineralized dung and rich in spherulites and ashes, indicate that the shelter was used for pastoral purposes since the earliest Neolithic occupation, but more intensively during the Chassey Neolithic (Late fifth-Early fourth millennium) (Binder et al. 1993, in press). Charcoal analysis has shown that the impact of pastoral practices on the vegetation remained low until the end of the fifth millennium but increased markedly during the 3rd millennium BCE. It also shows the exploitation of diverse patches of a mosaic vegetation, probably linked to a staged agro-sylvo-pastoral system based on the exploitation of the resources from various altitudes (Battentier et al. 2015). Several domestic activities also took place at the site, in particular an abundant and distinctive production of ceramic wares (Basso et al. 2006; Gomart et al. 2017). Numerous hearths and waste from everyday life suggest that the shelter was used as a dwelling by shepherd-potter groups. A set of burials has also been discovered in the Cardial levels (Mid6th millennium BCE) (Zemour et al. 2016). Agriculture is attested since the earliest Neolithic by the presence of cereal grains in the Impressa levels, which are amongst the oldest in France (Binder et al. 1993; Guilaine et al. 2007), and various tools linked with agricultural activities or with grain processing, such as sickle blades or grindstones. Seashell gathering is also attested during the 6th millennium BCE.

The stratigraphy is particularly detailed from the 6th to the 5th millennia BCE (235 stratigraphic units grouped in 30 clusters). The present study focusses on this period, during which the shelter was used for diverse activities, sometimes successively and sometimes simultaneously. Phytolith analysis is part of a set of investigations implemented in order to hone our understanding of the chrono-stratigraphy and of the archaeological occupations. Despite the fact that ongoing studies have not as yet yielded all their results, the data currently available already provide us with a good picture not only of the activities carried out on the site but also of some aspects of the socio-economical organization through time (Binder et al. in press). Like most of these shelters and caves used during the Neolithic in such contexts, Pendimoun is considered to have been a seasonal settlement. The key challenge facing us in terms of the Neolithic in general, and this site in particular, is to understand the nature, periodicity and rhythm of the seasonal occupations, and consequently to understand the position of the site in the territory exploitation network. During the earliest Neolithic (Impressa), the site was inhabited by a group of farmers (Rowley-Conwy et al. 2013), who cultivated cereals and raised sheep. The activities that took place on the site were diverse and also included some hunting, gathering of plants (acorns) and of seashells as well as the manufacture of ceramics; these activities seem to have been conducted at different seasons of the year, during long-lasting occupations of the shelter.
Afterwards, during the Cardial Neolithic, the shelter seems to be used during briefer but repeated periods, although the spectrum of activities remains globally the same (livestock keeping, pottery production), with the noticeable exception of the use of the shelter to bury the dead. The importance of hunting in the economy is not clear, partly because of difficulties in the identification of Suideae (wild boar vs. domestic pig). During the transition phase to the Square Mouthed Pottery (SMP) culture, the shelter was used for the penning of herds, but also for various other domestic and craft activities, which suggest long-lasting occupations. A hiatus of several centuries isolates the first SMP settlement from the rest of the Neolithic sequence, which exhibits an increasing specialization of the site towards pastoral activities: during the Middle Neolithic, the occupation is typical of the grottes-bergeries (sheepfold caves) known elsewhere in the Alps and the northwestern Mediterranean area during that period (Delhon et al. 2008; Angelucci et al. 2009; Martin et al. 2011 and references therein); afterwards, during the Bell Beaker period, the pastoral economy switches to rearing cattle rather than small ruminants (Binder et al. 1993). Because Pendimoun is a reference site for the first stage of the Neolithic in the area and because the following levels (from mid-fifth to the end of 3rd millennia BCE) provided less artefacts and ecofacts, this paper focuses on the earliest Neolithic sequence, i.e. the Impressa first Neolithic, the Cardial Neolithic and the transition towards the SMP.

\section{Materials and method}

Phytoliths are microscopic opal silica particles produced in and between plant cells during the life of the plant. Due to their chemical composition, they are usually well preserved in various contexts, even when the organic plant remains are decomposed (Kibblewhite et al. 2015). Because of the high phytolith content of grasses (including cereals) and the specificity of the forms produced by the Poaceae, these bioremains are appropriate for reconstructing agricultural practices, cereal processing and the diet of herbivores (including domesticated species). Seventeen stratigraphic units were sampled for phytolith analysis, in order to give clues to the relationships between the human groups that frequented the shelter during Prehistory and the surrounding vegetation. In particular, we aimed to gain a better understanding of the share of agriculture in the economy of the Early Neolithic societies by tracking cereal remains, and of the management of herds through the phytolith record of their diet. Focusing on the most promising archaeological levels, phytolith analysis was carried out on 1 sample from a Mesolithic burial and 16 samples covering most of the 6th millennium BCE (Impressa, Cardial, Early SMP). Our analysis targets chronocultural complexes for which sharply focused documentation

\begin{tabular}{|l|l|l|l|l|}
\hline Journal : Large 334 & Article No: 739 & Pages : 12 & MS Code : 739 & Dispatch : 13-7-2019 \\
\hline
\end{tabular}


concerning the exploitation of vegetal resources is lacking, in particular the pioneer stages of the Neolithic (Impressa), but also the earliest stages of the establishment up of Middle Neolithic cultural complexes (SMP).

All of the samples come from sheltered zones of the site, where the sedimentary sequence was shown to have been protected from major erosion. Most of the samples come from the northern sector of the site and were analysed by C.D.; two samples recovered from the southern sector and previously analysed by P.V. are also included into the present study. A small number of samples originate from the fill of identified structures, while most are from the sedimentary matrix of the archaeological levels (Table 1).

Around $2 \mathrm{~g}$ of sediment from each sample were processed by A.M. at the CEPAM-CNRS Laboratory, following the laboratory's routine protocol for phytolith extraction. The sediment is sieved $(200 \mu \mathrm{m})$ after soaking $(12 \mathrm{~h})$ in demineralized water for deflocculation of clays. The fine fraction is then treated first with concentrated hydrochloric acid and then with potassium hydroxide in an ultrasonic hot bath. After several rinses, phytoliths are concentrated by heavy liquid separation using a Thoulet solution $(\mathrm{d}=2.35)$. Once dried, the phytoliths are dispersed on a slide in a drop of immersion oil and protected by a cover-glass sealed with resin. Phytolith identification is carried out through a transmitted light microscope, at a magnification of $\times 1,000$. Where needed, polarizer/analyser devices are used to differentiate amorphous silica opal from potentially birefringent particles. The protocol used provides a very clean phytolith extract, but it does not allow the observation of spherulites. These are identified in the sediment through other analytic means (Brochier in Binder et al. 1993) and do not fall in the scope of the present study. Phytolith identification is based on a morphotypic classification prior to a taxonomic one, due to the multiplicity (a single species may produce various different morphotypes) and the redundancy (the same morphotype may be produced by various different species) of phytolith production (Rovner 1971; Brown 1984). As regards the terminology used for the description of the morphotypes, we endeavour to follow the latest recommendations of the International Committee for Phytolith Nomenclature (ICPN 2.0, ICPT in press). In order to guarantee the statistical reliability of the results, we ensured that more than 200 classified phytoliths were counted for each studied sample.

\section{Results}

All of the samples provided abundant and well preserved phytoliths (Table 1). It was not difficult to observe satisfactory quantities of significant forms on the slides, as phytoliths proved to be abundant and well preserved in every sample. As a result, identifiable phytoliths counts vary between 167 and 409 . Weathering and surface alteration (Fredlund and Tieszen 1997) were rarely observed. The phytoliths were nearly always represented by single-cell particles: connected silicified cells, also known as silica skeletons, were only rarely encountered in five different samples, mainly from the sedimentary matrix (Impressa, Cardial, SMP transitions levels) but also from one Impressa combustion structure. They account for 0.3 to $1.2 \%$ of the assemblages in which they have been observed, i.e. 1 to 4 individuals per sample. These multicelled phytoliths are mainly made up of grass epidermal cells, apart from one example of contiguous silicified grass bulliform cells. The observed morphotypes (Fig. 2) mainly relate to the Poaceae (grass) family. Phytoliths attributed to dicots are rare over all, but reach noticeable values in the southern area. They are represented by globular morphotypes (SPHEROID ORNATE) and by probable epidermal cells (tabular polygonal morphotype). Concerning grass phytoliths, the morphotypes produced in the vegetative parts of the plants (culm, leaves) are abundant. Among them, Elongate entire, Elongate sinuate, Acute bulbosus are very common and cannot be taxonomically identified further. The silicified bulliform cells have also been allocated to the general grass family due to a lack of published descriptions and of modern comparison reference material for the area. They were represented by the BULLIFORM FLABELlate and BlOCKY morphotypes. Although BlOCKY forms are not unequivocal (ICPT in press), the overall composition of the phytolith spectra, dominated by grass phytoliths, points to silicified bulliform cells. A silica skeleton made of articulated BLOCKY phytoliths, likely silicified bulliform cells, was observed. BULLIFORM FLABELLATE and BLOCKY morphotypes are subsumed into the BuLLIFORM category in Table 1 and Fig. 3. On the other hand, short cells allow us to distinguish between several Poaceae sub-families (Twiss et al. 1969; Twiss 1992). Crenate morphologies characterize the Pooideae subfamily, while RONDEL is more widespread, but, in a temperate context, can be interpreted as mainly originating from the Pooideae family too. BiLOBATE morphotype, also previously known as "dumbells", is mainly produced by the Panicoideae subfamily. SADDLE, only present in low amounts in Pendimoun sediment, is frequently used as a diagnostic the Chloridoideae, despite that it can be found in other related subfamilies (ICPT in press). Nearly all of the species of wild grasses from temperate Europe are Pooideae, as are the first cereals domesticated in the Middle East and then introduced into Europe (Triticum spp., Hordeum spp.). Panicoideae are only represented by a small number of genera in middle latitudes of Western Europe, particularly Setaria (wild millets), Digitaria and Echinochloa. Domesticated millets also belong to the Panicoideae subfamily. 


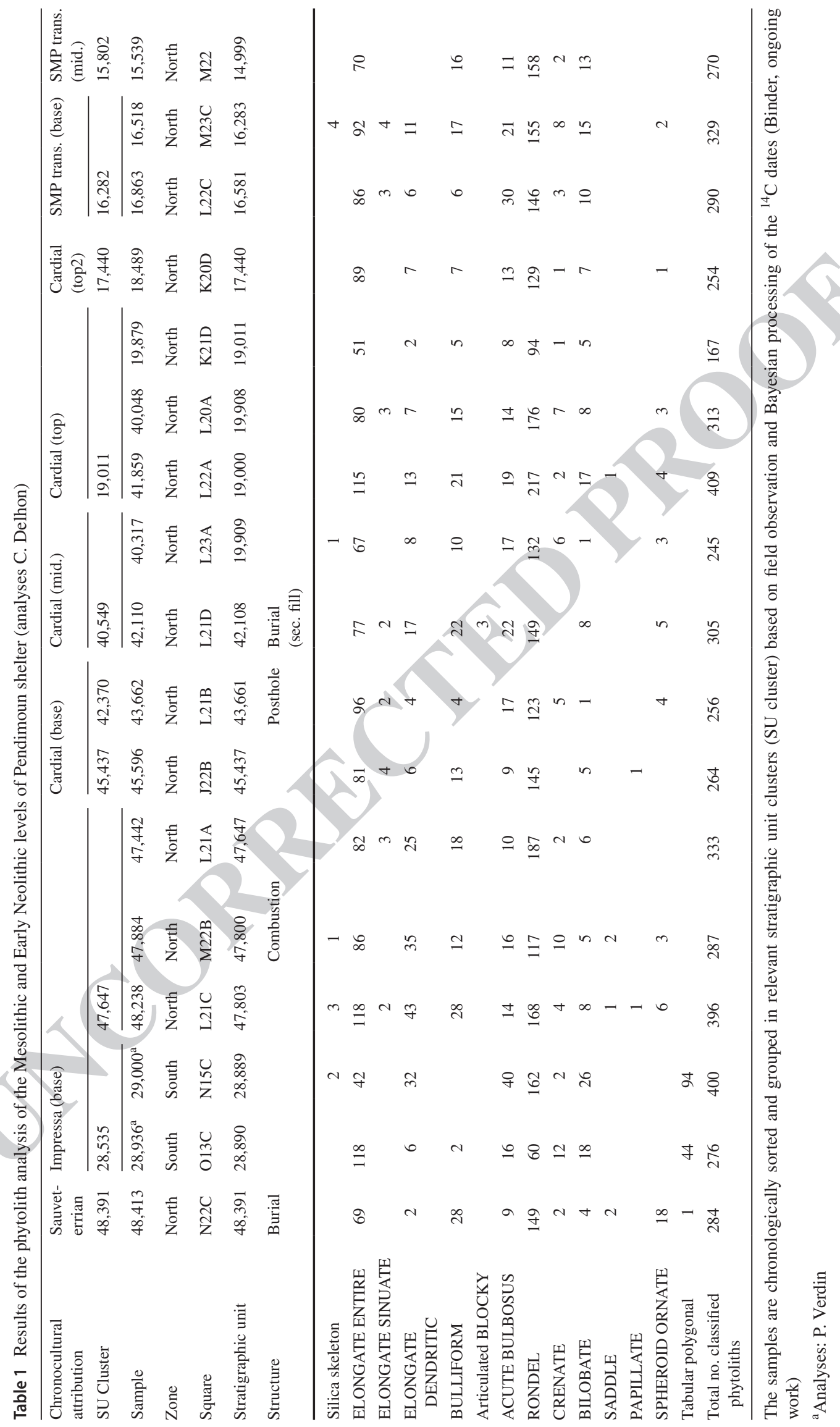



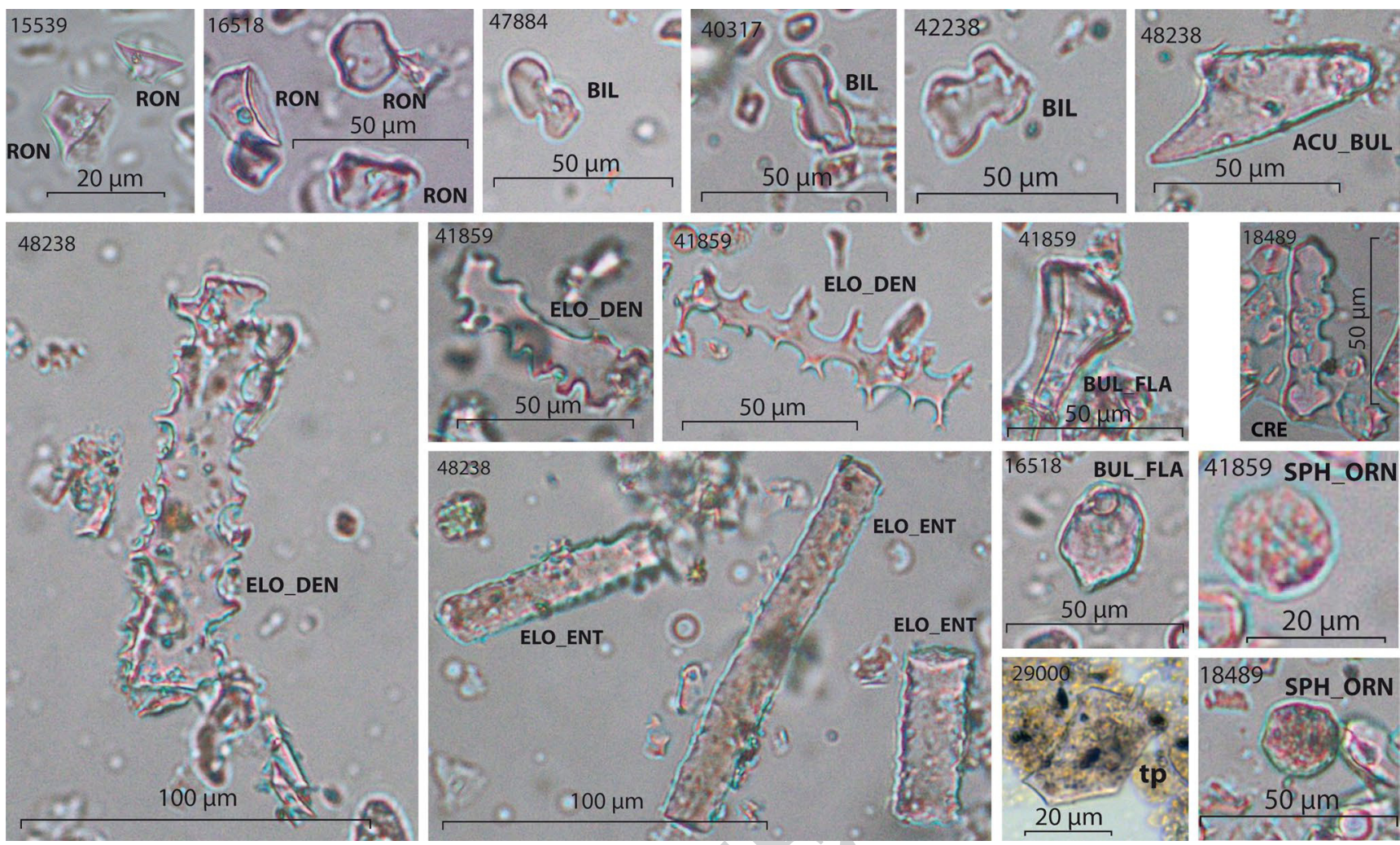

Fig. 2 Photographs of the main phytolith morphotypes found at Pendimoun: Rondel (RON), Bilobate (BIL), Crenate (CRE), Elongate DENDritic (ELO_DEN), Elongate entiRe (ELO_ENT), Bulliform

Finally, the Chloridoideae subfamily is mainly distributed in intertropical areas, but it is nevertheless represented in southern France by Cynodon dactylon (Bermuda grass). The common reed, Phragmites australis, which belongs to the Arundinoideae subfamily, also produces saddleshaped short cells (Ollendorf et al. 1988), but this species is restricted to wetlands, especially in Mediterranean areas. Morphotypes from grass inflorescence bracts have also been observed, in the form of ELONGATE DENDRITIC and scarce PAPILlate (Parry and Smithson 1966; Rosen 1992).

Most of the spectra show a strong dominance of grass phytoliths (Fig. 3). In the Neolithic samples from the northern sector, dicot morphotypes show a discontinuous curve and only account for nil to $1.6 \%$ of the total. The pattern is completely different for the samples from the southern area, in which dicots phytoliths, in the form of tabular polygonal particles interpreted as leaf epidermal cells (tp in Fig. 2) have high values: 16.1 and $23.5 \%$. The variability of the phytolith spectra might be linked to a spatial distribution of the activities inside the shelter, but more samples from the southern zone would have been necessary to assess the extent of the phenomenon and to propose further interpretations. The Sauveterrian burial, in the northern area, also exceeds the Neolithic levels in flabellate (BUL_FlA), Acute bulbosus (ACU_BUL), Spheroid ORNATE (SPH_ORN), tabular polygonal (tp). The number in the left corner refers to the phytolith sample this sector in terms of dicots, which represent $6.7 \%$ of its phytolith content.

\section{Discussion}

\section{Livestock diet}

In pastoral sites like Pendimoun, phytolith accumulation is thought to be mainly due to shepherds bringing vegetation into the cave as bedding or fodder for the livestock, and also, depending on the frequency and the duration of their presence in the shelter, to the transportation of plant material within the digestive systems of the animals. Nevertheless, it remains difficult to determine whether these microremains mainly stem from livestock alimentation or if they could also partly result from the use of plants for other purposes. Based on ethnoarchaeological observations, a significant presence of multi-cell phytoliths (also called silica-skeleton) is sometimes considered as a marker of dung accumulation (Portillo et al. 2014) or of the presence of bedding (Cabanes et al. 2009). Yet, these forms are rather rare in Pendimoun. Nevertheless, in some cases, like in La Grande Rivoire, the abundance of spherulites indicates that

\begin{tabular}{|l|l|l|l|l|}
\hline Journal : Large 334 & Article No : 739 & Pages : 12 & MS Code : 739 & Dispatch : 13-7-2019 \\
\hline
\end{tabular}




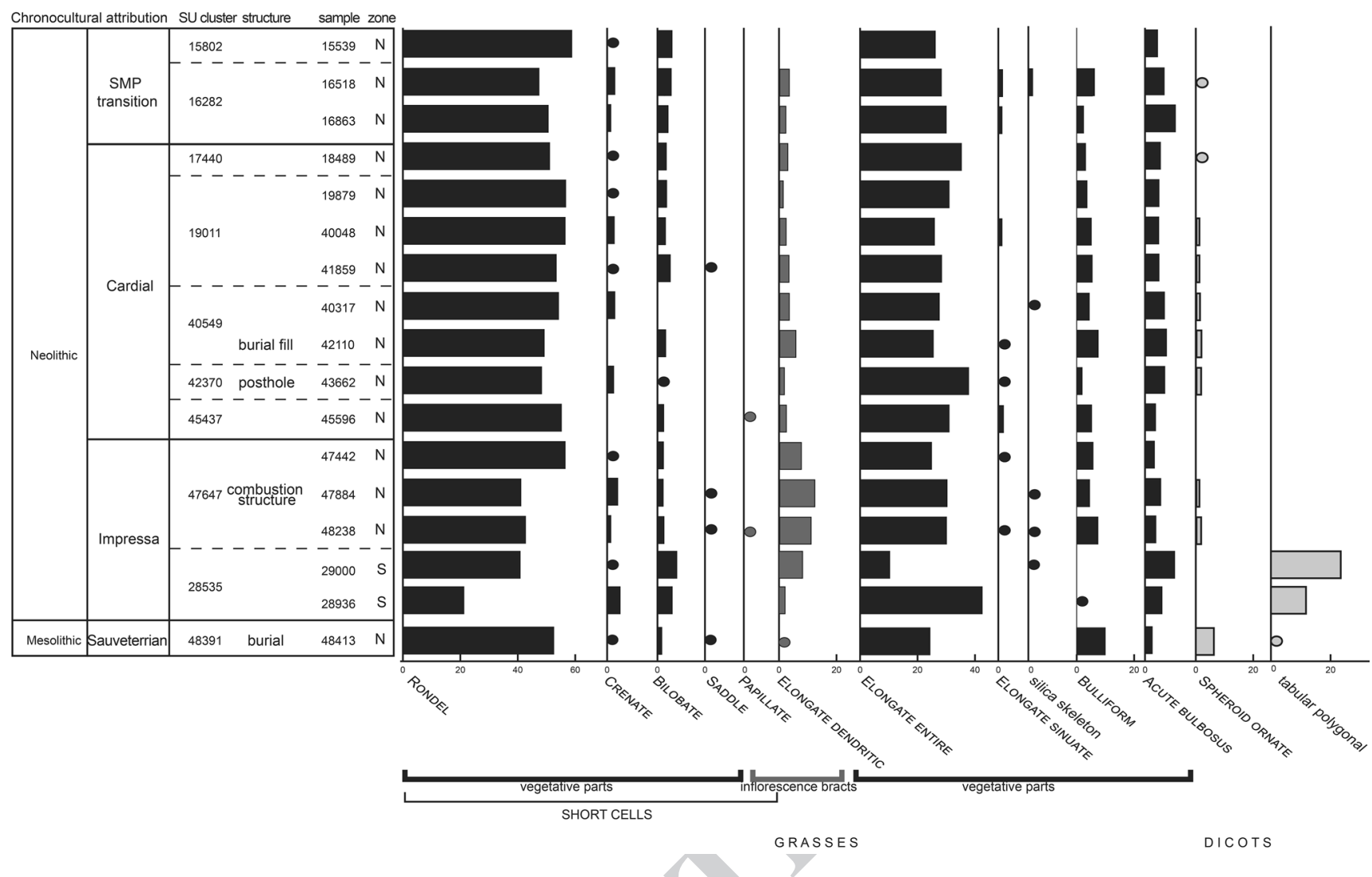

Fig. 3 Results of the phytolith analysis of the Mesolithic and Early Neolithic levels of the Pendimoun shelter

sediment mainly derives from dung, despite the fact that the abundance of grass multi-cell phytoliths remains low (from 0 to 6\%, Delhon 2014). Taphonomical processes may enhance the breakage of these forms into single-cell particles. Moreover, depending on environmental factors and on the age of the vegetal tissues, multicelled phytoliths may not be present in the browsed grasses. Thus, the absence or scarcity of silica skeletons at Pendimoun is not sufficient to rule out the possibility that the phytolith assemblages derive from dung accumulation. Focusing on the northern zone, it thus seems that the livestock mainly fed on grasses, either brought into the shelter by the shepherds or grazed from the surrounding vegetation. Even though phytolith production is far more important in grass then in dicots (Delhon 2010), the presence of dicot phytoliths suggests that such plants were introduced into the shelter, albeit in smaller quantities compared to grasses. In dicots from temperate areas, phytolith production seems to be mainly concentrated in leaves (epidermal cells) and wood (globular morphotypes), although it remains very low in the latter (Scurfield et al. 1974; Kondo et al. 1994; Alexandre et al. 1997; Albert and Weiner 2001; Delhon 2010). Wood was used on the site, at least for fuel, as documented by the presence of scattered charcoal in all of the levels. Nevertheless, the scarcity of dicot phytoliths indicates that branches and leaves were probably not used as bedding or for feeding animals.

These results are similar to those reported from two Ligurian sites (Italy). In the phytolith analysis of Riparo di Pian del Ciliegio shelter (transition to and early SMP: 5000-4800 to 4600-4300 BCE), only grass morphotypes are reported (Arobba and Caramiello 2009), while at the Arene Candide Cave there is a "sharp prevalence" of grass origin (Nisbet 1997). In contrast, the use of tree branches bearing leaves and/or flowers has been demonstrated on various other Neolithic shelters in southern France (grottes-bergeries) (Thiébault 2005). At La Grande Rivoire (Isère, Vercors massif, Alps), the use of tree fodder is clearly indicated by very high proportions of dicot phytoliths (most of the time between 30 and 50\%) throughout the Neolithic (Delhon et al. 2008). At Pendimoun, it seems that the livestock mainly fed on grasses, either freely browsed or brought for this purpose into the shelter by the shepherds. This is consistent with the data from charcoal analysis, which failed to identify any evidence of leaf-fodder either in the taxonomic spectra (Battentier et al. 2015) or in the diameter of the branches (absence of charcoal fragments characteristic of twig morphology) (Battentier 2018). Perhaps a climatic gradient might explain the need to gather tree fodder only at certain

\begin{tabular}{|l|l|l|l|l|}
\hline Journal : Large $\mathbf{3 3 4}$ & Article No : 739 & Pages : 12 & MS Code : 739 & Dispatch : 13-7-2019 \\
\hline
\end{tabular}


altitudes or latitudes (for example at La Grande Rivoire and not at Pendimoun) where it would have compensated for a lack of vegetation. However husbandry practices could also be involved, such as the duration of the period when the animals were stabled, the season during which the shelter was used as a sheepfold or the type of animals being kept (sheep and/or goats) and their proportions. Concerning the northern sector of Pendimoun, it is noteworthy that the only structure which is not linked with pastoral activity is also the one that provides the best evidence for the potential use of dicots: the phytolith spectra for the Sauveterrian (Mesolithic) burial contain $6.7 \%$ dicot phytoliths, including a fragment of silicified epidermis. Although we are dealing with a single sample, it is tempting to think that this result could be linked to Sauveterrian funerary practices.

\section{Cereal processing on the site}

Morphotypes from inflorescence bracts (ELONGATE DENDRITIC and Papillate) are very rare among Pendimoun grass phytoliths (Fig. 4a), except in the Impressa levels where they reach $12 \%$ of the identified phytoliths. In the other levels, the only instance in which they attain frequencies higher than $3.3 \%$ is the sample from the Cardial burial $(42,110)$, where they could originate from the Impressa levels. In fact, the funerary pit may have been filled using the surrounding sediment, including the layers deposited during the preceding Impressa period. In archaeological contexts, an accumulation of inflorescence bract phytoliths is generally considered as a sign of an important contribution of cereals to the phytolith record. In cereals, fertile parts (ears) usually represent a greater part of the total biomass than is the case for most European wild grasses, and the increase of seed mass that characterizes domestic grasses could have led to an increase of glume silicification (Novello and Barboni 2015), both phenomena leading to higher amounts of inflorescence bract phytoliths than in wild species. Moreover, even when the archaeological record results from the accumulation of culm and leaves, cereals are most likely to have been harvested when ears were mature, which is not necessarily the case for wild grasses; this leads to the systematic occurrence of significant amounts of inflorescence bract phytoliths. The very Early Neolithic levels at Pendimoun also yielded preserved cereal grains (emmer wheat, einkorn and barley) and grindstones (Binder et al. 1993, in press). In the southern part of the site, one of the research team (P.V.) has identified two different types of ElONGATE DENDRITIC phytoliths (Fig. 5). Nevertheless, the range of intraspecific variation of ElONGATE DENDRITIC is considerable (Ball et al. 2017) and makes it hazardous to connect these forms to the cereal taxa identified through macro-remains analysis. Inflorescence bract phytoliths clearly do not occur in the same quantities as on later sites where cereal-related activities have been proved with certainty. For example, in the Bronze Age layers of El Mirador cave (Sierra de Atapuerca, Spain), inflorescence bract phytoliths reach $30 \%$ in an assemblage (facies
Fig. 4 Phytolith ratios. a Ratio of the proportions of ELONGATE DENDRITIC phytoliths (from inflorescence bracts) versus Elongate ENTIRE and E. SINUATE (from culms and leaves). $\mathbf{b}$ Ratio of BILOBATE short cells versus Rondel and CREnATE short cells
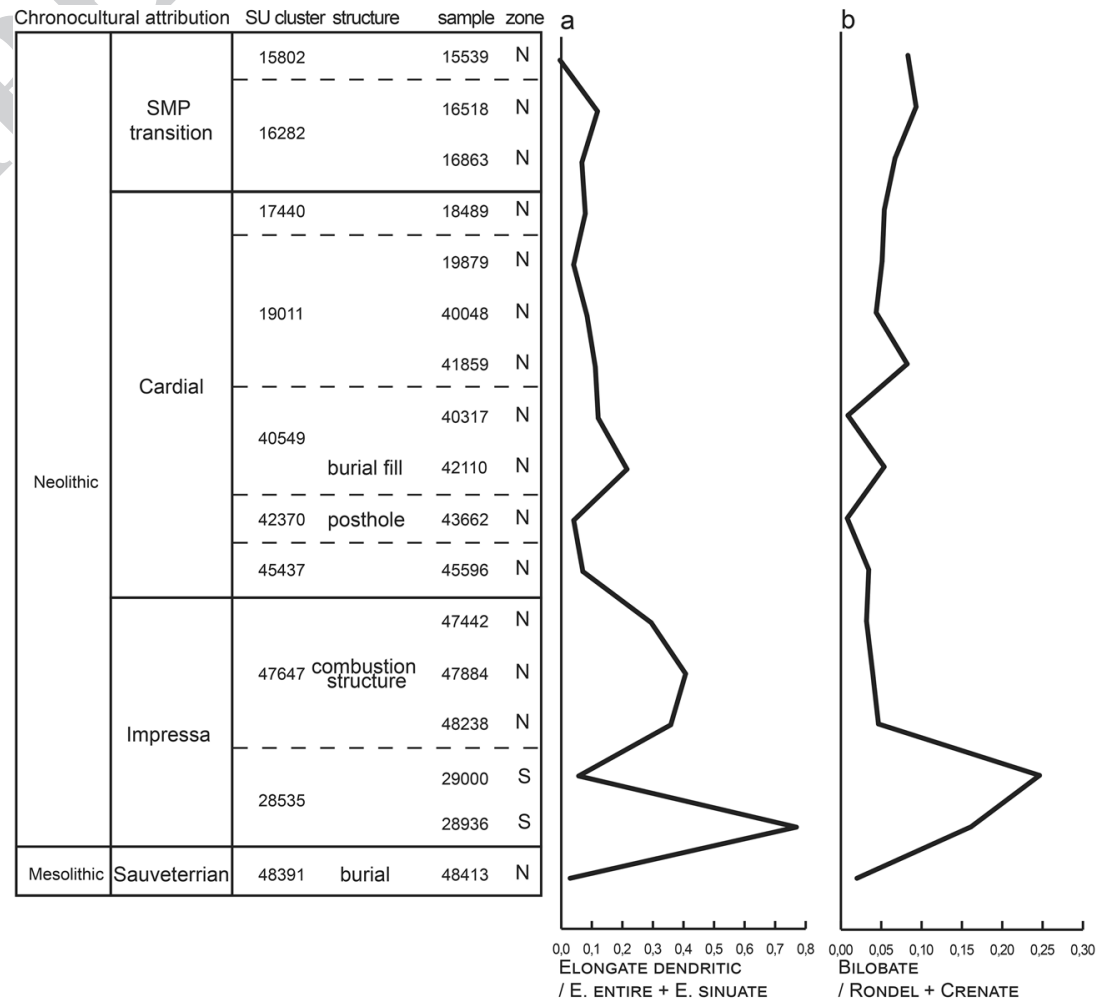

\begin{tabular}{|l|l|l|l|l|}
\hline Journal : Large 334 & Article No : 739 & Pages : 12 & MS Code : 739 & Dispatch : 13-7-2019 \\
\hline
\end{tabular}



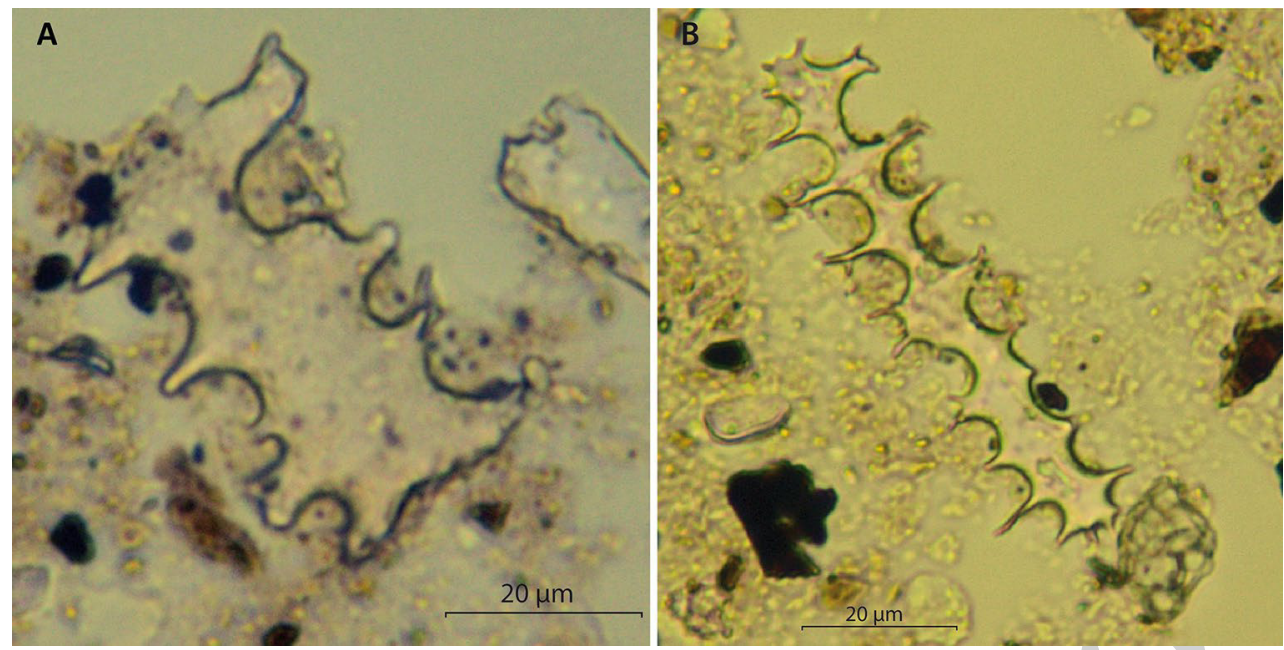

Fig. 5 Main types of Elongate DENDritic (a and $\mathbf{b}$ ) distinguished by P.V. in Pendimoun phytolith assemblages

f) considered to be made up of crop-processing (threshing/ winnowing or milling/pounding) residues and also rich in cereal pollen (Cabanes et al. 2009). Nevertheless, our opinion is that the amount of inflorescence bract phytoliths found in the Impressa levels, which is not only high per se but is also significantly higher than what is observed in all of the other levels of the sequence, is evidence of an input of grass inflorescences in the shelter which could be linked to in situ processing of cereals during the earliest Neolithic.

With the exception of the Impressa levels, the very low presence of inflorescence bract phytoliths seems to indicate that no crop processing occurred at the site in other periods of occupation. Cereal macroremains were identified in the Cardial levels and in very low quantities in the SMP transition levels (Binder et al. in press). These cereals, presumably consumed by the shelter's inhabitants, seem to have been introduced onto the site in a dehusked form. At Els Trocs (Early and Middle Neolithic, Pyrenees, Spain, 1,564 m a.s.l., end of the sixth/beginning of the third millennia: Rojo Guerra et al. 2013), very low amounts of inflorescence bract phytoliths have been interpreted not only as suggesting an absence of cereal processing but also as a sign of a very low input of grass inflorescences, either domesticated or wild, at the site (Lancelotti et al. 2014). The authors suggest that the site was occupied before the complete formation and silicification of the inflorescence bracts, which is achieved at the end of the summer at the altitude which the site is located. Concerning the Cardial and SMP occupations of Pendimoun, the low but variable amount of inflorescence bract phytoliths could also be evidence for the grazing of young grasses, before they bear mature inflorescences, i.e. at an early stage of their life-cycle. Nevertheless, it is more difficult to connect it to a specific season of occupation because of the location of the site at a lower altitude (ca. $700 \mathrm{~m}$ a.s.1.) in a Mediterranean context in which the favourable season for seed production may be longer.

\section{Seasonality of pastoral activities as recorded by phytolith assemblages}

Grass short cells are very abundant and mainly belong to the Rondel and Crenate types, which is not surprising given the importance of Pooideae in the area. Nevertheless, BILOBATE is regularly encountered and in certain instances is quite abundant (around 5\% of the total) (Fig. 4b). As a comparison, the forms mainly attributed to Panicoideae are not reported at Pian del Ciliegio (Arobba and Caramiello 2009), are nearly absent at La Grande Rivoire (Delhon et al. 2008) and seem to show very variable amounts at Arene Candide (Nisbet 1997). In the area of Pendimoun, during the Neolithic, only three different grasses may have contributed to the production of Bilobate: Setaria sp. (mainly Setaria viridis), Digitaria sanguinalis and Echinochloa crus-galli. Such plants were thus present near the shelter and/or used by the dwellers during the Neolithic. All of these grasses exhibit a $\mathrm{C}_{4}$-metabolism and display a ruderal behaviour. Echinochloa seems to be the least likely of the three as it

\begin{tabular}{|c|c|c|c|c|c|c|c|c|c|c|c|}
\hline & J $\quad F$ & $M$ & $\mathbf{A}$ & $M$ & $\mathrm{~J}$ & $\mathrm{~J}$ & $\mathbf{A}$ & $\mathrm{s}$ & 0 & $\mathbf{N}$ & $\mathbf{D}$ \\
\hline Setaria sp. & & & & & & & & & & & \\
\hline Digitaria sanguinalis & & & & & & & & & & & \\
\hline Echinochloa crus-galli & & & & & & & & & & & \\
\hline
\end{tabular}

Fig. 6 Life calendar (dark grey) of the panicoid grasses which could have grown near Pendimoun shelter during the Neolithic, from sprouting (light grey) to seed maturity (black) (data from Institut Technique de l'Agriculture Biologique 2012)

\begin{tabular}{|l|l|l|l|l|}
\hline Journal : Large 334 & Article No : 739 & Pages : 12 & MS Code : 739 & Dispatch : 13-7-2019 \\
\hline
\end{tabular}


needs humid contexts, but its presence cannot be excluded. All of these plants are annual, with short so-called "summer" lifecycles (for example no more than 8 weeks for $S$. viridis) (Fig. 6). According to modern data for weeds from organic crops (Institut Technique de l'Agriculture Biologique 2012), germination occurs from the end of spring to the middle of autumn (June/September for $S$. viridis, May/October for $E$. crus-galli, June/October for D. sanguinalis) and seed maturity, followed by plant decay, is reached at the end of summer or during autumn (August/October for S. viridis and $E$. crus-galli, September/October for D. sanguinalis). Because they contain significant amount of BILOBATE short cells, most of the studied levels should therefore record plant collection or grazing during summer (broadly speaking: from the end of spring to the beginning of autumn). Combining this evidence with the absence or scarcity of inflorescence bracts phytolith (in most of the SMP and Cardial levels) allow us to narrow down the season of pastoral use of the shelter to the end of spring and early summer, before the complete silicification of inflorescence bracts cells. The levels where BiLOBATE are lacking $(43662,40317)$ might record winter/ early spring frequentation of the site, unless a heterogeneous use of plants through time and space led to their absence in the posthole $(43,662)$ and when the site was used for burial (40,317). Nevertheless, a survey of the actual life-cycles of these plants in the area around the Pendimoun shelter would clarify the picture of suggested seasonality of the Neolithic frequentation of the shelter for pastoral purposes. Indeed, we cannot exclude the possibility that these short-lived grasses may be able to take advantage of temporarily favourable climatic conditions so as to colonize limited areas outside of their "normal" growing season.

\section{Conclusions}

The phytolith spectra from the Pendimoun shelter indicate an important use of grasses, mainly wild Poaceae. Because mineralized dung is a major component of the sediment, we assume that these plants microremains mainly originate from digested animal food. However, the phytolith spectra also partly originate from a mixture of plant used for various purposes. It can be easily argued that cereals, which were probably processed inside the shelter during the earliest Neolithic, were intended to feed the human inhabitants rather than their flocks.

In the most probable case, i.e. that phytoliths mainly result from the plant parts eaten by the animals, the low level of morphotypes attributed to dicots indicates that livestock management during the Early/Middle Neolithic did not require any additional food supply in the form of leaf fodder. Thus, the available vegetation in the pasturelands was probably sufficient to address the needs of the farmers. The reasons why livestock fodder was supplemented with leafy or flowering branches in some pastoral Neolithic sites (for instance at La Grande Rivoire) and not in others (for instance at Pendimoun) requires further investigation. The recourse to additional food supply may have been necessary in certain areas due to the duration of the bad season, or because of pastoral practices resulting in the presence of livestock in some areas (mountains) before or after the period when pasturelands where accessible or productive (before the melting of snow or the greening of the vegetation, after the first snowfalls or the senescence of grasses, in cases of severe drought...); the species of animal being raised (goat, sheep, cow...) may also have an influence. Woody leafy branches are easy to dry and stock over few months, and are thus convenient for filling a seasonal shortage of fresh vegetation. Tree fodder may also have been used simply to facilitate the housing of flocks (Battentier et al. 2016) and would have allowed the spacing of the browsing periods. It is broadly acknowledged that mobility was a component of the Neolithic farming systems in the south of France, as shown by the existence of various types of sites, some of them exhibiting an organization typical of long-term settlements associated with crop production, others being more occupied for shorter periods of time and dedicated to hunting activities, and others, like Pendimoun, which provide evidence for probable seasonal pastoral occupation. These different patterns illustrate the increasing complexity of the territory exploitation system, in the form of a network of more or less specialized sites used during certain periods of the year and by different elements of the social groups (Binder 1991; Rowley-Conwy 1991; Beeching et al. 2000; Bréhard et al. 2010; Martin 2014). Nevertheless, the season(s) when the pastoral shelters (grottes-bergeries) were occupied, the duration of the occupation and its frequency (once a year, several times a year, repeatedly in a given period of the year) are difficult to specify, and could differ from one site to another.

In the area concerned, where the winters are mild, the observation that leaf fodder was not used gives no information on the season, but the data from Pendimoun offer other clues concerning that issue: the grasses were consumed before the development of the inflorescences, which seems to exclude a period from mid-summer to the beginning of autumn, and the presence of panicoid grasses restricts the window to a period focused on summer (broadly speaking). Finally, phytolith data make it probable that pastoral activities in Pendimoun during the Early/Middle Neolithic principally took place from the end of spring to the beginning of the summer.

Of course, this initial hypothesis concerning seasonality now has to be verified by means of other kinds of data. Other phenomena could explain part of the observed spectra, for example the use of grass fodder (harvested during spring and stocked to be used later), which is still not evidenced 
for the Early Neolithic period, or intense browsing which would prevent the plants from flowering. Moreover, it must be kept in mind that, thanks to their very short lifecycle, the panicoids may have been able to sprout and grow locally outside of the usual season, thanks to temporarily favourable climatic conditions. Besides, the seasonality of pastoral activities may have changed over time. During the Impressa period, pastoralism is combined with agriculture and the shelter seems to be almost continuously occupied, while during the Cardial/SMP periods shepherds may have used the shelter at certain period of the year only, in a system where pastoralism alternated with other activities.

Acknowledgements This paper is based on a lecture presented at the 10th International Meeting of Phytolith Research, held in Aix-enProvence in September 2016. We wish to thank the organizers of the meeting, Doris Barboni, Jean-Dominique Meunier, Anne Alexandre and Marine Pasturel, as well as the Scientific Committee for giving us the opportunity to present our work. The authors are grateful to two anonymous reviewers for their constructive comments on the manuscript and to Katharina Neumann for drawing our attention on the newly completed ICPN 2.0 and for providing significant improvements concerning phytolith nomenclature.

\section{References}

Albert RM, Weiner S (2001) Study of phytoliths in prehistoric ash layers using a quantitative approach. In: Meunier JD, Colin F (eds) Phytoliths: applications in earth sciences and human history. Balkema Publishers, Lisse, pp 251-266

Alexandre A, Meunier JD, Lézine AM, Vincens A, Schwartz D (1997) Phytoliths: indicators of grassland dynamics during the Late Holocene in intertropical Africa. Palaeogeogr Palaeoclimatol Palaeoecol 136:213-229

Angelucci DE, Boschian G, Fontanals M, Pedrotti A, Vergès JM (2009) Shepherds and karst: the use of caves and rockshelters in the Mediterranean region during the Neolithic. World Archaeol 41:191-214

Arobba D, Caramiello R (2009) Indagini archeobotaniche sul deposito neolitico del Ripario di Pian del Ciliegio. Quad Mus Archeol Finale 5:117-130

Ball T, Vrydaghs L, Mercer T, Pearce M, Snyder S, Lisztes-Szabó Z, Petõ Á (2017) A morphometric study of variance in articulated dendritic phytolith wave lobes within selected species of Triticeae and Aveneae. Veget Hist Archaeobot 26:85-97

Basso E, Binder D, Messiga B, Riccardi MP (2006) The Neolithic pottery of Abri Pendimoun (Castellar, France): a petro-archaeometric study. In: Maggetti M, Messiga B (eds) Geomaterials in cultural heritage. Geological Society Special Publications 257. The Geological Society, London, pp 33-48

Battentier J (2018) Gestion des espaces forestiers provençaux et ligures au Néolithique: approche anthracologique. PhD Thesis, Université Côte d'Azur

Battentier J, Thiébault S, Binder D, Théry-Parisot I, Carré A, Delhon C (2015) L'abri Pendimoun (Castellar, Alpes-Maritimes): nouvelles données sur l'évolution du couvert forestier et l'exploitation du milieu au Néolithique (5800-2000 ans cal. BCE). Quaternaire 26:277-290

Battentier J, Lepère C, Théry-Parisot I, Carré A, Delhon C (2016) La grotte de Pertus II (Méailles, Alpes-de-haute-Provence): exploitation du couvert forestier au chasséen récent (3850-3650 cal.
BC). In: Cauliez J, Sénépart I, Jallot L, de Labriffe P-A, Gilabert C, Gutherz X (eds) «De la tombe au territoire» \& Actualité de la Recherche. Actes des 11e Rencontres Méridionales de Préhistoire Récente, Montpellier (Hérault) 2014. Archives d'Écologie Préhistorique, Toulouse, pp 223-232

Beeching A, Berger J-F, Brochier JL, Ferber F, Helmer D, Sidi Maamar H (2000) Chasséens: agriculteurs ou éleveurs, sédentaires ou nomades? Quels types de milieux, d'économies et de sociétés? In: Leduc M, Valdeyron N, Vaquer J (eds) Sociétés et Espaces, Rencontres méridionales de Préhistoire récente. Archives d'Écologie Préhistorique, Toulouse, pp 59-79

Binder D (1991) Une économie de chasse au néolithique ancien: La grotte Lombard à Saint-Vallier-de-Thiey (Alpes-Maritimes). Monographies du Centre de Recherches Archéologiques 5. CNRS, Paris

Binder D, Brochier J-E, Duday H, Helmer D, Marinval P, Thiébault S, Wattez J (1993) L'abri Pendimoun (Castellar, AlpesMaritimes): nouvelles données sur le complexe culturel de la céramique imprimée méditerranéenne dans son contexte stratigraphique. Gall Préhist 35:177-251

Binder D, Lanos P, Angeli L et al (2017) Modelling the earliest northwestern dispersal of the Mediterranean Impressed Wares: new dates and Bayesian chronological model. Doc Praehist 44:54-77

Binder D, Battentier J, Bouby L et al (in press) First farming in the North-Western Mediterranean: evidences from Castellar-Pendimoun during the 6th millennium вCE. In: Gron KJ, Sørensen L, Rowley-Conwy P (eds) Farmers at the frontier: a Pan-European perspective on Neolithisation. Oxbow Books, Oxford

Bréhard S, Beeching A, Vigne J-D (2010) Shepherds, cowherds and site function on Middle Neolithic sites of the Rhône Valley: an archaeozoological approach to the organization of territories and societies. J Anthropol Archaeol 29:179-188

Brown DA (1984) Prospects and limits of a phytolith key for grasses in the Central United States. J Archaeol Sci 11:345-368

Cabanes D, Burjachs F, Expósito I, Rodríguez A, Allué E, Euba I, Vergès JM (2009) Formation processes through archaeobotanical remains: the case of the Bronze Age levels in El Mirador Cave, Sierra de Atapuerca, Spain. Quat Int 193:160-173

Delhon C (2010) Phytolithes et taphonomie, apport de l'expérimentation à la quantification des phytolithes dans les cendres de bois. In: Théry-Parisot I, Chabal L, Costamagno $\mathrm{S}$ (eds) Taphonomie des résidus organiques brûlés et des structures de combustion en milieu archéologique. P@lethnologie 2. Université Jean-Jaurès, Toulouse, pp 97-107

Delhon C (2014) Analyse phytolithique des niveaux de bergerie du Néolithique (coupes stratigraphiques S30 et S32). In: Nicod P-Y, Picavet R (eds) Fouille archéologique de la Grande Rivoire à Sassenage (Isère), rapport de fouille 2012-2014. Lampea, Aix-en Provence, pp 387-389

Delhon C, Martin L, Argant J, Thiebault S (2008) Shepherds and plants in the Alps: multi-proxy archaeobotanical analysis of Neolithic dung from "La Grande Rivoire" (Isère, France). J Archaeol Sci 35:2,937-2,952

Fredlund GG, Tieszen LL (1997) Calibrating grass phytolith assemblages in climatic terms: application to Late Pleistocene assemblages from Kansas and Nebraska. Palaeogeogr Palaeoclimatol Palaeoecol 136:199-211

Gomart L, Weiner A, Gabriele M et al (2017) Spiralled patchwork in pottery manufacture and the introduction of farming to Southern Europe. Antiquity 91:1,501-1,514

Guilaine J, Manen C, Vigne JD (2007) Pont de Roque-Haute (Portiragnes, Hérault). Nouveaux regards sur la néolithisation de la France méditerranéenne. Archives d’Écologie Préhistorique, Toulouse

Harvey EL, Fuller DQ (2005) Investigating crop processing using phytolith analysis: the example of rice and millets. J Archaeol Sci 32:739-752

\begin{tabular}{|l|l|l|l|l|}
\hline Journal : Large 334 & Article No : 739 & Pages : 12 & MS Code : 739 & Dispatch : 13-7-2019 \\
\hline
\end{tabular}


ICPT: Neumann K, Albert RM, Ball T, Scott Cummings L, Strömberg C, Vrydaghs L (in press) International Code for Phytolith Nomenclature (ICPN) 2.0. Ann Bot

Institut Technique de l'Agriculture Biologique (2012) Connaitre les adventices pour les maîtriser en grandes cultures sans herbicides - Annuelles germination d'été. http://www.itab.asso.fr/downloads/ desherb-meca/dm-brochure-adventices_6_ete.pdf. Accessed 1 Dec 2015

Kibblewhite M, Tóth G, Hermann T (2015) Predicting the preservation of cultural artefacts and buried material in soil. Sci Total Environ 529:249-263

Kondo R, Childs CW, Atkinson I (1994) Opal phytoliths of New Zealand. Manaaki Whenua Press, Lincoln

Lancelotti C, Balbo AL, Madella M et al (2014) The missing crop: investigating the use of grasses at Els Trocs, a Neolithic cave site in the Pyrenees (1564 m asl). J Archaeol Sci 42:456-466

Martin L (2014) Premiers paysans des Alpes. Alimentation végétale et agriculture au Néolithique. Tables des Hommes. Presses Universitaires de Rennes, Rennes

Martin L, Delhon C, Argant J, Thiébault S (2011) Un aperçu de l'élevage au Néolithique par l'archéobotanique. L'exemple d'une bergerie dans le Nord du Vercors. In: Lefèvre C, Denis B (eds) Le mouton, de la domestication à l'élevage. Ethnozootechnie 91. Société d'Ethnozootechnie, Toul, pp 37-45

Nisbet R (1997) The phytoliths from the Neolithic levels of Arene Candide. In: Maggi R (ed) Arene Candide: a functional and environmental assessment of the Holocene Sequence (Excavations Bernabo' Brea-Cardini1940-50). Memorie dell'Istituto Italiano di Paletnologia Umana 5. Ministero per i Beni Culturali e Ambientali, Roma, pp 113-118

Novello A, Barboni D (2015) Grass inflorescence phytoliths of useful species and wild cereals from Sub-Saharan Africa. J Archaeol Sci 59:10-22

Ollendorf AL, Mulholland SC, Rapp G Jr (1988) Phytolith analysis as a means of plant identification: Arundo donax and Phragmites communis. Ann Bot 61:209-214

Parry DW, Smithson F (1966) Opaline silica in the inflorescences of some British grasses and cereals. Ann Bot 30:25-538

Portillo M, Kadowaki S, Nishiaki Y, Albert RM (2014) Early Neolithic household behavior at Tell Seker al-Aheimar (Upper Khabur,
Syria): a comparison to ethnoarchaeological study of phytoliths and dung spherulites. J Archaeol Sci 42:107-118

Rojo Guerra M, Peña Chocarro L, Royo Guillén JI et al (2013) Pastores trashumantes del Neolítico antiguo en un entorno de alta montaña: secuencia crono-cultural de la Cova de Els Trocs (San Feliú de Veri Huesca). BSAA Arqueol 79:9-55

Rosen A (1992) Preliminary identification of silica skeletons from near eastern archaeological sites: an anatomical approach. In: Rapp G Jr, Mulholland SC (eds) Phytolith systematics: emerging issues. Plenum Press, New York, pp 129-147

Rovner I (1971) Potential of opal phytoliths for use in paleoecological reconstruction. Quat Res 1:343-359

Rowley-Conwy P (1991) Arene Candide: a small part of a larger pastoral system? Riv studi liguri 56:89-112

Rowley-Conwy P, Gourichon L, Helmer D, Vigne J-D (2013) Early domestic animals in Italy, Istria, the Tyrrhenian Islands and southern France. In: Colledge S, Conolly J, Dobney K, Manning K, Shennan S (eds) The origins and spread of domestic animals in southwest Asia and Europe. Left Coast Press, Walnut Creek, pp 161-194

Scurfield G, Anderson CA, Segnit ER (1974) Silica in woody stems. Aust J Bot 22:211-229

Thiébault S (2005) L'apport du fourrage d'arbre dans l'élevage depuis le Néolithique. Anthropozoologica 40:95-108

Twiss PC (1992) Predicted world distribution of $\mathrm{C}_{3}$ and $\mathrm{C}_{4}$ grass phytoliths. In: Rapp G Jr, Mulholland SC (eds) Phytolith systematics: emerging issues. Plenum Press, New York, pp 113-128

Twiss PC, Suess E, Smith RM (1969) Morphological classification of grass phytoliths. Soil Sci Soc Am J 33:109-115

Zemour A, Binder D, Coppa A, Duday H (2016) La sépulture au début du Néolithique $\left(\mathrm{VI}^{\mathrm{e}}\right.$ millénaire et première moitié $\mathrm{du} \mathrm{V}^{\mathrm{e}}$ millénaire cal BC) en France méridionale et en Italie: de l'idée d'une» simple «fosse à une typologie architecturale. Bull Mém Soc d'Anthropol Paris 29:94-111

Publisher's Note Springer Nature remains neutral with regard to jurisdictional claims in published maps and institutional affiliations.

\begin{tabular}{|l|l|l|l|l|}
\hline Journal : Large 334 & Article No : 739 & Pages : 12 & MS Code : 739 & Dispatch : 13-7-2019 \\
\hline
\end{tabular}




\section{Journal: $\quad 334$}

Article: $\quad \mathbf{7 3 9}$

\section{Author Query Form}

Please ensure you fill out your response to the queries raised below and return this form along with your corrections

Dear Author

During the process of typesetting your article, the following queries have arisen. Please check your typeset proof carefully against the queries listed below and mark the necessary changes either directly on the proof/online grid or in the 'Author's response' area provided below

\begin{tabular}{|l|l|l|}
\hline Query & Details Required & Author's Response \\
\hline AQ1 & Kindly check and confirm whether the corresponding author is correctly identified. & \\
\hline AQ2 & Please check and confirm the settings of Table 1. & \\
\hline AQ3 & Please update Refs. Binder et al., ICPT et al. (in press) with complete details. & \\
\hline
\end{tabular}

